\title{
NA PROXIMIDADE REFLEXIVA DE UM... TRAVESSEIRO!
}

\author{
Adriana Claudia Martins ${ }^{1}$
}

Se Na Cama, que é obra do pintor francês e pós-impressionista Toulouse-Lautrec (1864-1901),

se no leito, que acolhe o meu, o teu Ser.

Se presente,

em O livro do travesseiro, na minuta da japonesa e literária Sei Shônagon,

se rascunho de alguém que dorme...

É dito ser um...

Travesseiro!

Se repleto de algodão ou plumas, espuma ou viscoelástico,

Se clama ou não, serve à cabeça e até descansa um corpo.

O que importa?

Ainda assim, é tão-somente o...

Travesseiro!

Se almofada lombar, recheada de ilusões.

Se enredo das canções de amor, poema falso

Se terapia nas lágrimas, amigo culpado.

\footnotetext{
${ }^{1}$ Doutora em Educação na Universidade Federal de Santa Maria/RS e Doutoranda em Letras Estudos Literários nessa mesma Instituição; Mestre em Letras - Estudos linguísticos na Universidade Católica de Pelotas/RS; E-mail: teacheradrianacm@ hotmail.com
} 
Se afável no abraço possível, declarado confesso.

Se esconderijo do que precisa ser invisível, camuflado no oculto.

Se esperançoso durante todo o dia, coxim sozinho.

Se companhia do pensar reflexivo, vigília cúmplice.

Se consciência na insônia, substantivo comum.

Se personalizado no gênero masculino,

Ah, sim, então, confundido com a almofada!

De fato, um fofo até nas angústias.

Ainda e assim, é tão-somente o... Travesseiro.

No entanto, sua história e axioma decorrem de longa data...

Pois, $\operatorname{sim} .$.

É recordado desde 994 d.C.,

e nesses... Mais de mil anos passados,

o Travesseiro agita a própria razão existencial.

Com o valor de um momento único, Ele cabe na própria essência!

Reflete...

Refrata!

Ele analisa a passagem da minha vida, da tua vida!

Ele sabe das questões éticas de nossa vivência irrepetível.

Ele conhece o nosso silêncio, o meu, o teu.

Ela escuta a voz que movimenta a nossa identidade.

E, então, após a passagem do dia,

Ele se expande no tecido da escura noite.

Para, enfim, dos meus segredos se aproximar, 
para saber de teus mistérios...

Sim, estamos falando...

Exatamente Nele, no Travesseiro.

Esse, que conosco fala e que invade nossas verdades,

que alcança a alma, a minha e a tua!

Esse, que registra a si mesmo na história e não nos deixa dormir.

Esse mesmo Travesseiro que ajuíza o tempo atravessado...

Nas cores da...

Fronha. 